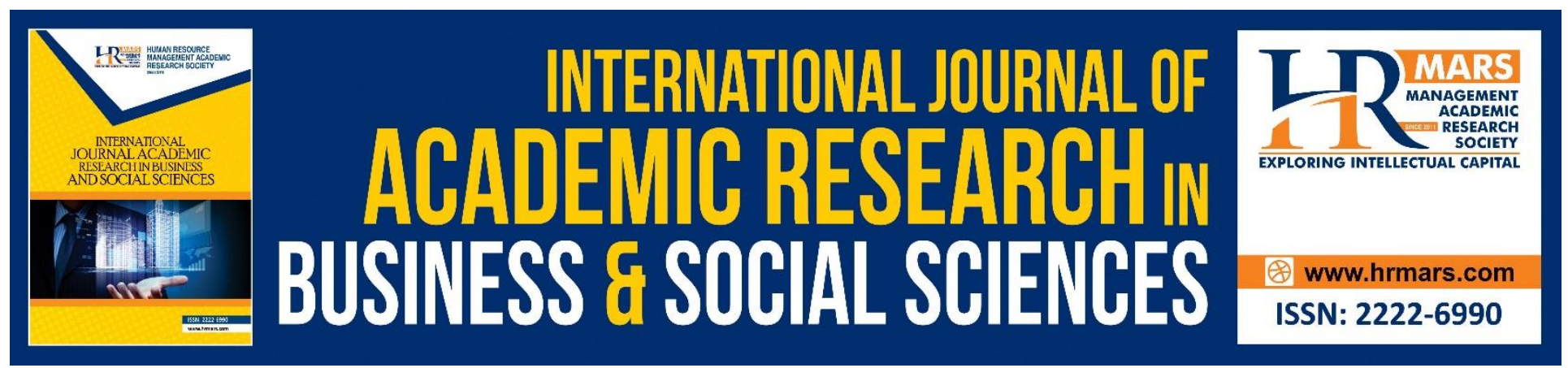

\title{
Effects of Using Expressive Arts Therapy in Group Counseling on Managing Delinquent Adolescents' Anger
}

Sabihah Johan, Ku Suhaila Ku Johari, Sh Marzety Adibah Al Sayed Mohamad, Nor Hamizah Ab Razak, Nadziroh Md Zubir

To Link this Article: http://dx.doi.org/10.6007/IJARBSS/v8-i12/5439

DOI: $10.6007 /$ IJARBSS/v8-i12/5439

Received: 11 Nov 2018, Revised: 18 Dec 2018, Accepted: 26 Dec 2018

Published Online: 15 Jan 2019

In-Text Citation: (Johan, Johari, Mohamad, Razak, \& Zubir, 2018)

To Cite this Article: Johan, S., Johari, K. S. K., Mohamad, S. M. A. A. S., Razak, N. H. A., \& Zubir, N. M. (2018). Effects of Using Expressive Arts Therapy in Group Counseling on Managing Delinquent Adolescents' Anger. International Journal of Academic Research in Business and Social Sciences, 8(12), 2293-2201.

Copyright: (C) 2018 The Author(s)

Published by Human Resource Management Academic Research Society (www.hrmars.com)

This article is published under the Creative Commons Attribution (CC BY 4.0) license. Anyone may reproduce, distribute, translate and create derivative works of this article (for both commercial and non-commercial purposes), subject to full attribution to the original publication and authors. The full terms of this license may be seen

at: http://creativecommons.org/licences/by/4.0/legalcode

Vol. 8, No. 12, 2018, Pg. 2293 - 2301

http://hrmars.com/index.php/pages/detail/IJARBSS

JOURNAL HOMEPAGE

Full Terms \& Conditions of access and use can be found at http://hrmars.com/index.php/pages/detail/publication-ethics 


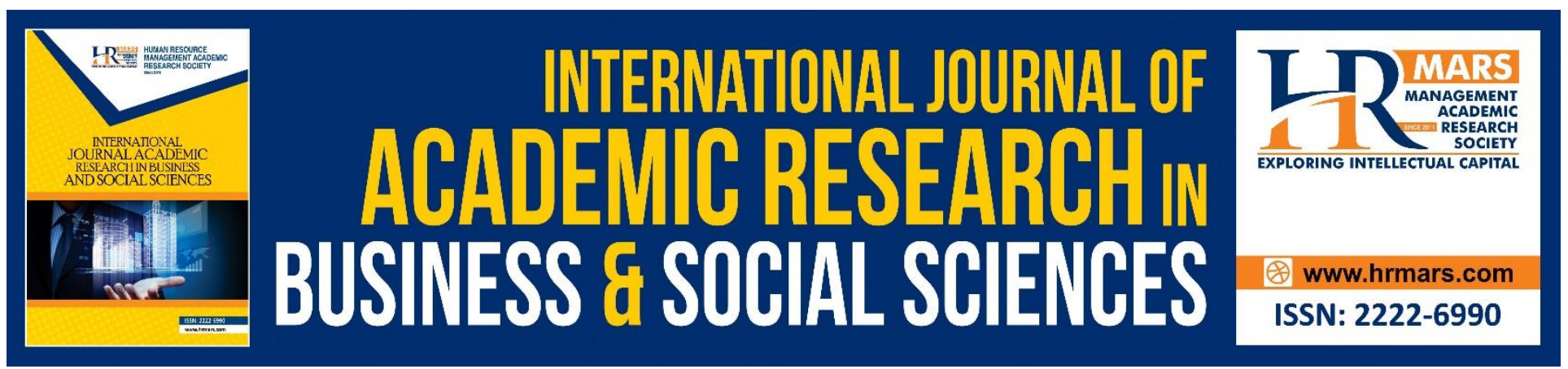

\title{
Effects of Using Expressive Arts Therapy in Group Counseling on Managing Delinquent Adolescents' Anger
}

\author{
Sabihah Johan ${ }^{1}$, Ku Suhaila Ku Johari², Sh Marzety Adibah Al \\ Sayed Mohamad ${ }^{3}$ Nor Hamizah Ab Razak ${ }^{4}$, Nadziroh Md Zubir ${ }^{5}$ \\ Faculty of Education, Universiti Kebangsaan Malaysia, 43600, Bangi \\ Selangor, MALAYSIA \\ Email:suhaila@ukm.edu.my
}

\begin{abstract}
Expressive arts theraphy is a multimodal therapy of art that is practiced as an individual psychological recovery process. The purpose of this study was to identify the effects of expressive art therapy in group counseling on delinquent adolescents' anger. Quasi-experimental designed with pre and post test methods are used in this study. A total of 84 delinquent adolescents living in moral rehabilitation institutions, aged 14 to 21 years old were selected using purposeful sampling. Clinical Anger Scale (CAS) is used to measure the dependent variable and supported by the analysis of documents. The results showed that there was a significant reduction in adolescents' anger. Research implications are discussed from theoretical aspects, counselling professionals, other researchers and Social Welfare Department. In short, Expressive Arts Therapy has been an alternative to expressing latent feelings and an effective communication medium.
\end{abstract}

Keywords: Expressive Arts Therapy, Anger, Delinquent Adolescents, Quasi Experiment

\section{Introduction}

The rapid development of the world in facing the era of globalization has led to changes in the structure of society, especially the family institution. Couples working in a basic family are commonly known features. This has contributed to the challenge of balancing work stress and giving attention to family. This situation leads to the fragility of family institution and the neglection of responsibility to the family. Many cases of social problems have been reported started from the situation of the fragility of this institution.

The increase in cases of social problems is clearly alarming with statistical reports released by Jabatan Kebajikan Masyarakat Wilayah Persekutuan Kuala Lumpur (JKMWPKL) throughout 
2015 from January to July by the statistics section showing January to March the reported cases were 47 cases. The most widely reported behavioral cases are such as possessing stolen property and stealing, possessing and distributing drugs, illegal racing, robbery, raping, molesting and gangsterism (JKMWKL, 2015). The increase in this case clearly shows that of the delinquent adolescent symptoms is getting serious. These adolescents must be given the attention of various parties as they are the heirs and leaders of leadership in the future. The issue of social symptoms or delinquency experienced by adolescents should be seen as a serious scenario as the issue is increasingly becoming more complicated.Counselors play an important role in preventing and treating issues related to this delinquent adolescents. The counseling profession is no longer foreign in Malaysia as an alternative to assist many troubled adolescents. Counseling was first introduced in Malaysia and the counseling service began in the 1960s (Aminah, 1987). Setting the counseling service starts at the school after the service circulars direct each school to have their counseling teacher (Sidek, Abdul Halim \& Zuria, 2006). The counselor must understand the client's culture, ethics and religion as the client's personality, attitude and behavior are shaped from cultural and religious values (Briggs \& Rayle, 2005).

Delinquent among adolescents is a behavior that violates the norms and values of the living and the thus members of the community cannot accept the perpetrator's action whether it is subjected to court action or not (Azizi at el, 2012). Their involvement in these social issues should be seen as a warning to us that there is an internal conflict especially the emotional conflict experienced within themselves. One of the conflicts experienced by adolescents involved with this delinquency problem is the emotional stress that involves anger. To compensate for the changes that occur in oneself, adolescents will face problems and conflicts. As a result, tension and emotional stress will occur in adolescents' life. The adolescent may choose to show the attitude of aggressiveness, rebellious, and unmanageable anger (Helman, 2010).

Anger is a common expression of human experience. Anger is considered to be a universal emotion that occurs when one feels disturbed, depressed, failed, humiliated, neglected, marginalized and conflicts between psychological, oral thoughts and mechanisms (Helman, 2010). Since recently, studies have focused on the relationship between adolescents and the emotion of angry. This is due to an increase in school violence cases which are playing truant, bullying and gangsterism (Fives, Fuller, Kong, \& DiGiuseppe, 2011). Helman (2010) states that students who have low self-sustaining ability will express anger and have a risk of being involved in aggressive and violent cultural behaviors. In this study, the thing that need to be focused on is the effectiveness of using expressive art therapy against the anger of these delinquent adolescents. The researcher wants to determine the extent to which the use expressive art therapy has an impact on the angry emotions that want to be studied.

Natalie Rogers (2004) said that expressive art therapy is the expression of a person through art to understand and explore themselves and gain a sense of self-awareness. Expressive art therapy combines several forms of artistic expression involving movements, music, visual art, creative writing, games and imagery. Expressive Art Therapy can also be summarized into an integrated therapy of various therapies and also use a variety of multi-modal art. Additionally, the use of Expressive Art 
Therapy is also not only applied in the field of counseling knowledge either individually or in groups, but is also used in many other areas such as used by family therapists and marriages, psychiatrists, pastoral care specialists, psychogists, social workers and psychiatrists nurse (Gladding, 2011).

Therefore, in this study, researchers use expressive art therapy as a tool and as a means of giving a treatment and a positive impact on anger among delinquent adolescents. This study uses expressive art therapy in group counseling sessions as an intervention. According to Fadilah Zaini \& Maisarah Ishak (2006) counseling is a helpful communication profession that is widely practiced for problematic adolescents who have problems in behavior and emotional disturbances.

Nowadays, practitioners in the relationship want to help deal with various issues during the counseling process by placing one step into counseling sessions as a more creative intervention session.

\section{Literature Overview}

Delinquent adolescents need unconditional support and guidance from various parties to deal with psychological problems as well as social and emotional adjustments. Generally these delinquent adolescents not only think differently but also have different feelings when compared to their peers. As a result, these groups are easily affected and vulnerable to social and emotional issues and they feel a significant alienation, difficulty interacting, self-concept and low social communication. (Maizatul Akmam, 2007).

Counselors play an important role and are responsible for helping delinquent adolescents starting from school for facing social and emotional problems as well as various types of problems (McEachern, 2001). In addressing this issue, counselors need to have a good strategy and counseling approach that is different from what is commonly practiced. These delinquent adolescents need a way out and a sense of intellect to give them an effort to identify and overcome the problems they face. If this cannot be fulfilled, these adolescents will face the risk of depression, anxiety and prolonged stress. This situation is likely to lead to more serious and deviant treatment when they reach adulthood.

In this regard, expressive art therapy is seen as the most appropriate approach and is a technique that can be used for these delinquent adolescents. It can be practiced in individual counseling sessions or group counseling sessions (McEarhern, 2001). This is because the approach in Expressive Art Therapy for example drawing, coloring, writing and using emotional cards is a nonthreatening and safe creative strategy to be practiced (Geldard \& Geldard, 2004). This kind of creative strategy can help delinquent adolescents expressing their feelings, describing their thoughts and releasing their internal emotions that have been hurt (Natalie, 2012).

The application of the expressive art therapy helps clients to interpret, explain, and manage emotions about the problems they face. This method is believed to be able to provide a positive value to the conventional therapeutic process by taking into account that each client is unique and special. This application also does not focus on the artwork result such as its form of perfection or artistic value, but rather this method focuses more on internal processes that occur within the client. The client does not need to be creative, but this method provides clients with an extraordinary internal experience from the activities provided by the counselor. 
According to Gladding (1995), creativity is very important to counselors and clients in helping clients and counselors to look at the issues from different aspects and more positive perspectives. In this aspect, the counselor is a psychologically stable professional group and has the basic skills and the ability to provide therapeutic settings to these groups. Therefore it is the responsibility of the counselor to support the effectiveness of Expressive Art Therapy as a profession intervention in counseling.

\section{Research Methodology}

\section{Research Design}

The design of this study is an experimental quasi design involving pre-test and post-test and it is specially designed to evaluate effectiveness. This quasi-experimental study is carried out by researchers to measure the effects of stimuli or action on a variable and control the effects of external variables or those that have no relation to research objectives (Noraini, 2013). This study uses pretest and post-test design on treatment groups and control groups. Subject selected using purposive sampling. In this study, the treatment group will receive an intervention using Expressive Art Therapy for 12 sessions. Meanwhile, the control group did not receive any intervention.

\section{Population and Location}

The population of this research is in a youth rehabilitation center in the state of Terengganu. Adolescents who have been involved with various delinquent behaviors are placed in this rehabilitation center. The selection of the location of the research was based on the suitability of the respondents of the research which meets the criteria of the research objectives. The sample was from 14 years to 21 years old. The researcher divided the sample into two groups in which there are 42 peoples in the treatment group and 42 peoples in the control group. Samples of treatment groups undergo expressive art therapy sessions while the control group samples do not undergo any intervention and treatment.

\section{Research Instrument}

This study uses a questionnaire of anger, The Clinical Anger Scale (CAS), which was built by Dr. William E. Snell (1995). Researchers have translated the questionnaire. This set of questionnaires is divided into two sections, part A contains information about respondents' backgrounds which are age, family position, educations level, living with whom and where to live. Section B contains 20 questionnaires related to the scale of anger.

\section{Findings}

The results of the data analysis showed that the use of expressive art therapy had the effect of reducing the level of anger between pre-test and post-test with the mean of the difference before and after the session was 0.452 with the value $(t=2.009, p=0.050)$. It is concluded that the use of expressive art therapy affects the reduction of the treatment group's level of anger. This finding was supported by interviews from respondents who said that their angers are so obvious that they are very angry at the past, unable to accept the reality and angry to the person who them to be admitted 
to a moral rehabilitation center. For example the sketch of the drawing of anger and hatred that have been produced is:

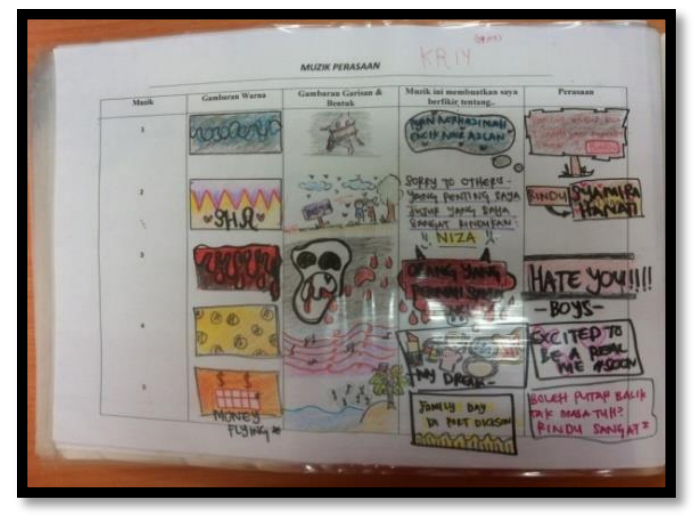

Creative result S01

However, the anger was subdued and seen decreasing and diminished by the statement that was explained:

'saya sedar sekarang...kesilapan saya sendiri apa yang jadi dulu...saya marah pada mereka, tapi kemarahan itu berkurang apabila saya boleh meluahkan perasaan saya, saya dapat berkongsi dan saya mula tahu hikmah yang saya perolehi..'

Plus, with the result of expressive art therapy that sketched which is a free and colorful butterfly. Respondents added, the butterfly painted was a feeling of joy, relief and happiness after undergoing expressive art therapy sessions.

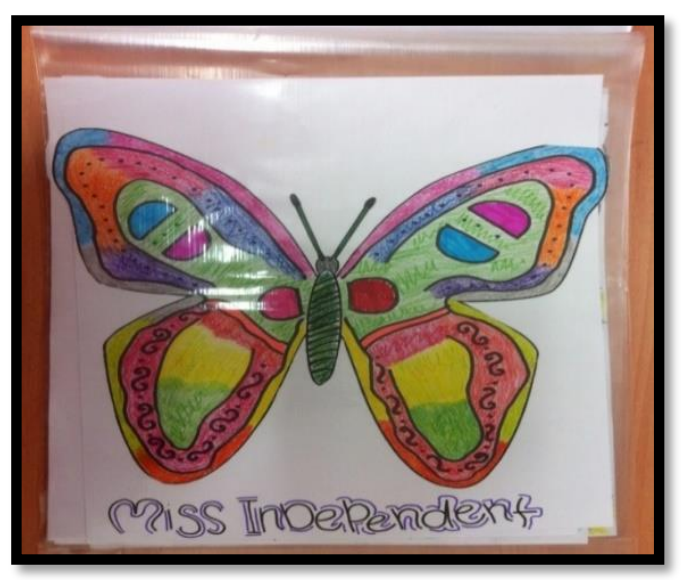

Creative result $\mathrm{SO} 2$ 
The same situation went by the S02 who wanted to go home and build a new life with the family. Respondent also share through the full range of butterflies drawing activities.

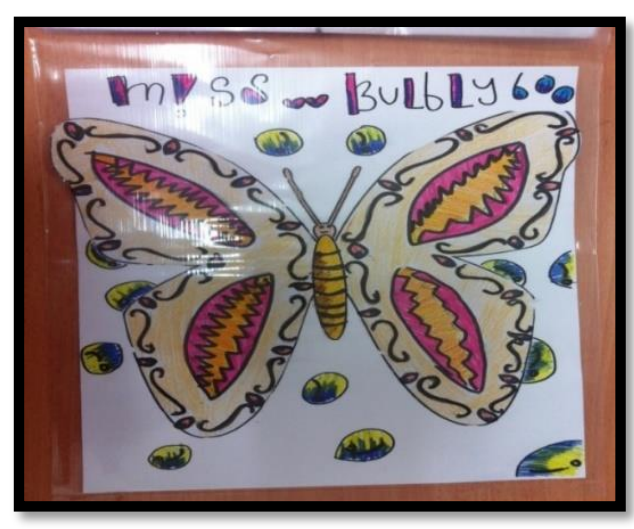

Creative result $\mathrm{SO3}$

"I want a complete and happy family like everyone else, I do not want to live in silence anymore. I want to fly chasing success and happiness with my family without a longing anger. " (SO2)

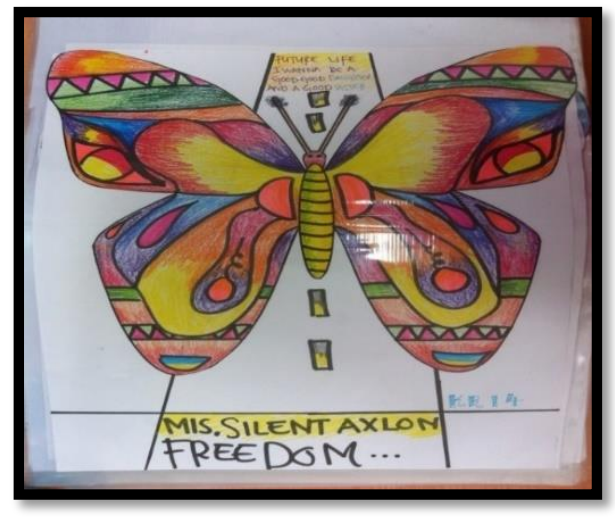

Creative result SO4

Based on experience undergoing expressive art therapy sessions, all respondents respond positively. Respondents explain in the butterfly drawing sketch that the counseling session uses expressive art therapy to create self-awareness, and awareness from other peer experiences.

\section{Discussion and Implications}

The findings show that there is a significant difference before and after the use of expressive art therapy to the adolescents' anger of the treatment group. This is can be seen through the difference in mean score of anger before and after the test. In this study the respondents were made 
up of respondents who were unable to control and defer anger before undergoing expressive art therapy sessions. It is clearly seen through the symptom of throwing artistic tools on other members of the group, as well as the behavior of being rude to friends who oppose. The findings of the study were supported by the analysis of art therapy documents showing the butterfly story sketches by respondents with colorful illustrations picturing a better future ahead. Respondents said anger could be controlled and they no longer resent with past stories.

After undergoing therapy sessions, the findings have reduced the level of anger of the respondents in line with the findings of Ramin, Masoumeh, \& Naderah, (2014) who explained the expressive art therapy affects the aggressive adolescent anger. Ramin et al study, (2014) by using the Art Therapy Program approach for two months managed to control the anger of the subjects involved, as well as enhanced their self-concept. In addition, McArdle \& Byrt, (2001) study on expressive writing also demonstrated significant improvements in various physical health measures, decreased number of people visiting physicians and better functioning of the immune system. The writing approach in Expressive Arts Therapy improves health in many ways, such as improvements in expression of anger, stress, and depression (Heather \& Jeremy, 2010).

The implications of the study can be discussed as a social innovation to assistant care practitioners, especially counselors to apply them in their actual service. Rafidah \& Noriah (2013) stated that the use of art therapy in counseling can help counselors obtain more information from clients. The counselor also acquires additional skills that enable the counselor to handle the counseling process smoothly and effectively. Such therapeutic processes lead clients to express what they conceived unaware of which they have been locked up by their own emotional disorders. The implications of the use of expressive art therapy in the field of counseling have helped the client through the process of emotional and feelings expression which the effects help the client reduce emotions of anger within themselves.

\section{Conclusion}

Expressive art therapy is as effective as 'tools' to explore the feelings felt and kept by the respondents in this study. The use of expressive art therapy in the session can help the adolescents express their feelings of stress, resentment and anger buried through artistic activities. Respondents in the study expressed their feelings through the painting, color and writing that they experienced more easily and session sharing became more profound. Document data analysis supports the quantitative data obtained and shows the data more robust, accurate and effective. This therapy can reduce the emotional level of anger experienced by delinquent adolescents in this study.

\section{References}

Yahaya, A., Hashim, S., Boon, Y., Ramli, J. \& Azizi, N. E. (2012). Penyelewengan tingkahlaku remaja:Punca dan rawatan.UTM Press

Piaw, C. Y. (2006). Kaedah dan Statistik Penyelidikan: kaedah penyelidikan buku 1. Malaysia:McGrawHill

Piaw, C. Y. (2012). Asas Statistik Penyelidikan. (Edisi Ke-2). Malaysia: McGraw-Hill 
INTERNATIONAL JOURNAL OF ACADEMIC RESEARCH IN BUSINESS AND SOCIAL SCIENCES

Vol. 8, No. 12, Dec, 2018, E-ISSN: $2222-6990$ C 2018 HRMARS

Zaini, F. \& Ishak, M. (2006). Peranan Kaunselor Dalam Pembangunan Pelajar. Kajian Kes Terhadap Kaunsleing Kelompok Kolej Universiti Kejuruteraan Dan Teknologi Malaysia. UTM. Johor

Fives, C. J. (2003). Anger, aggression, and irrational beliefs in adolescents. Dissertation Abstracts International: Section B: The Sciences and Engineering, 64(2). (2003-95016-105).

Fives, C. J., Kong, G., DiGiuseppe, R., \& Fuller, R. (2011). Anger, Aggression and irrational beliefs in adolescents. Cognitive Therapy and Research, 35(3), 199-208, doi: 10.1007/s10608-009-92933.

Helman, A. (2010). A cognitive-behavioral anger management comic book for adolescents. Dissertation Abstracts International: Section B: The Sciences and Engineering, 72(1). (201199140-484).

Idris, N. (2013). Penyelidikan dalam pendidikan. Kuala Lumpur: McGraw Hill Education

Samuel, T. G. (2011). The Creative Arts in Counseling. Fourth edition. American Counselling Association 